\title{
Cassava starch edible coating incorporated with propolis on bioactive compounds in strawberries
}

\section{Revestimento com fécula de mandioca incorporada com própolis nos compostos bioativos em morangos}

\author{
Ariela Betsy Thomas ${ }^{1 *}$, Rita de Cássia Mirela Resende Nassur², \\ Ana Carolina Vilas Boas' ${ }^{1}$, Luiz Carlos de Oliveira Lima ${ }^{1}$
}

\author{
'Universidade Federal de Lavras/UFLA, Lavras, MG, Brasil \\ ${ }^{2}$ Empresa Brasileira de Pesquisa Agropecuária/EMBRAPA, Semiárido, Petrolina, PE, Brasil \\ *Corresponding author: arielabbt@gmail.com \\ Received in june 24, 2015 and approved in october 26, 2015
}

\begin{abstract}
Strawberry is a fruit appreciated throughout the world due to its attractive quality attributes and stands out due to its high phenolic compound content, which positively contribute to biological properties of nutritional interest. The objective of this study was to evaluate the effect of cassava starch coatings incorporated with propolis combinations on the phytochemical content and the maintenance and increase of the strawberry antioxidant activity. The treatments were $3 \%$ cassava starch (CS), $3 \%$ cassava starch + 33\% ethanolic propolis extract (CS + P33\%), 3\% cassava starch $+66 \%$ ethanolic propolis extract $(C S+P 66 \%)$ and control (C). The fruits were stored at $4{ }^{\circ} \mathrm{C} \pm$ $0.5^{\circ} \mathrm{C}$ and $90 \% \mathrm{RH}$ for 16 days, making up a completely randomized design with 4 treatments and 5 time evaluations. Vitamin $\mathrm{C}$, phenolic compound, anthocyanin, and antioxidant activity levels were evaluated through two methods. The coating with $66 \%$ of propolis promoted higher Vitamin C content than fruits submitted to the other treatments at 8 and 12 days of storage. For antioxidant activity, fruits treated with CS maintained a higher FRS percentage (free radical scavenging) at all time evaluations. Control fruits presented higher anthocyanin content at the last evaluation time when the highest antioxidant capacity, by the ABTS method (2,2'-azino-bis(3-ethylbenzothiazoline-6sulphonic acid)), was observed in fruits with CS and CS + P66\% treatments. There was an increase tendency of the phenolic content during storage in all evaluated fruits. The propolis concentrations used, however, were not sufficient to increase or maintain the antioxidant capacity and phenolic contents of strawberries.
\end{abstract}

Index terms: Phytochemicals; antioxidant; Fragaria ananassa.

\section{RESUMO}

O morango é um fruto muito apreciado em todo o mundo por apresentar atributos de qualidade atrativos para o consumidor e destacase por seu alto conteúdo de compostos fenólicos, contribuindo, positivamente, para propriedades biológicas de interesse nutricional. Objetivou-se, neste estudo, avaliar o efeito de combinações do revestimento de fécula de mandioca incorporado com própolis, sob o conteúdo de fitoquímicos e na manutenção e incremento da atividade antioxidante de morangos. Os tratamentos utilizados foram fécula de mandioca 3\% (CS), fécula de mandioca 3\% + extrato etanólico de própolis 33\% (CS + P33\%), fécula de mandioca 3\% + extrato etanólico de própolis $66 \%$ (CS+P66\%) e controle (C), sendo os frutos armazenados a $4{ }^{\circ} \mathrm{C} \pm 0,5^{\circ} \mathrm{C}$ e UR90\% por 16 dias, perfazendo um delineamento inteiramente casualizado com 4 tratamentos e 5 tempos de avaliação. Avaliaram-se teores de vitamina C, compostos fenólicos totais, antocianinas e atividade antioxidante, por dois métodos. O revestimento com $66 \%$ de própolis promoveu maior conteúdo de Vitamina $C$ que os frutos submetidos a outros tratamentos aos 8 e 12 dias. Para a atividade antioxidante, frutos tratados com CS mantiveram maior \%SRL (sequestro de radicais livres) em todos os tempos de avaliação. Frutos controle apresentaram maior teor de antocianinas no último tempo de avaliação, quando a maior capacidade antioxidante pelo método ABTS (2,2' -azino-bis(3-etilbenzotiazolina-6-ácido sulfônico)) foi observada em frutos com os tratamentos CS e CS + P66\%. Observou-se uma tendência ao aumento do teor de compostos fenólicos durante o armazenamento em todos os frutos avaliados. As concentrações de própolis utilizadas, no entanto, não foram suficientes para incrementar ou manter a capacidade antioxidante e o teor de fenólicos dos morangos.

Termos para indexação: Fitoquímicos; antioxidante; Fragaria ananassa.

\section{INTRODUCTION}

The strawberry (Fragaria ananassa Duch.) belongs to the Rosaceae family and is one of the most consumed and currently investigated non- climacteric fruits, having appearance, firmness, flavor and antioxidant content as its principal quality attributes (Vandendriessche et al., 2012). Like other small fruits, the strawberry is a great source of bioactive compounds, 
including polyphenols such as anthocyanins, phenolic acids, flavonols and tannins as well as vitamin $\mathrm{C}$ (Szajdek; Borowska, 2008; Oszmianski; Wojdylo, 2009), which are often correlated with the high antioxidant capacity of the fruit (Pinto et al., 2010). Anthocyanins, responsible for the red color, are quantitatively the most important phenolic compounds found in strawberry (Silva et al., 2007). Antioxidant compounds have the ability to donate electrons to the free radicals, reducing them to more stable and non-reactive species (Brewer, 2011; Podsedek, 2007), which protects the material against oxidative processes that modify cell membranes and biomolecules (Pokorný, 2007).

The attempt to reduce losses and maintain the fresh fruit quality for longer periods is one of the priorities of strawberry growers around the world. Edible coatings prepared from biopolymers consist of thin layers of edible material applied to foods that play an important role in their preservation and appearance (McHugh, 2000), acting as a barrier to different agents such as water vapor and some gases. Interest in the application of such treatments is becoming more popular due to the environmental protection feature and potential use in the food industry (Zahid et al., 2012). These materials also allow the addition of active compounds in their formulation, which may increase functional properties in order to enable them as potential alternatives in food preservation (SánchezGonzález et al., 2011).

Propolis is a resinous substance collected by honeybees from various plant parts (Katircioglu; Mercan, 2006). Due to its composition rich in flavonoids and phenolic acids (Bankova; Castro; Marcucci, 2000), propolis has high biological activity, including antioxidant, antibiotic, anti-inflammatory and antifungal activities (Scazzocchio et al., 2006). Zahid et al. (2013) were able to delay ripening in pitayas and increase the biosynthesis of nutritional components such as antioxidants and total flavonoids with the application of $0.5 \%$ propolis ethanolic extract.

Although there are some studies involving the application of propolis to improve quality and extend postharvest life of food, the use of this product, in combination with edible coatings, is still underexplored. In addition, reports about this subject have not been found for strawberries. Therefore, the objective of this study was to evaluate the effect of cassava starch coatings incorporated with propolis on the content of phytochemicals of nutritional interest and on the antioxidant activity of strawberries stored under refrigeration for 16 days.

\section{MATERIAL AND METHODS}

Strawberries of the 'Camino Real' cultivar grown in the city of Itutinga, MG, Brazil, were used. The cultivation area is located at $910 \mathrm{~m}$ of altitude, latitude $21^{\circ} 18^{\prime} 45^{\prime \prime} \mathrm{S}$ and longitude $44^{\circ} 41^{\prime} 15^{\prime \prime} \mathrm{W}$, with a climate characterized as humid temperate with dry winter and temperate summer. The average annual precipitation in the area is approximately $1400 \mathrm{~mm}$, with minimum and maximum values of $900 \mathrm{~mm}$ and 2100 $\mathrm{mm}$ respectively and an average annual temperature between 19 and $20^{\circ} \mathrm{C}$ (Minas Gerais, 2008). The fruits were harvested by hand at their point of commercial maturity ( $90 \%$ red), with an average weight of 36 grams, being selected based on appearance and absence of injuries and diseases. They were then taken to the Fruit and Vegetable Postharvest Laboratory of the Federal University of Lavras, where the field heat was removed (pre-cooling) and the fruits were washed and sanitized with sodium dichloroisocyanurate $\left(\operatorname{Hidrosan}^{\circledR}\right)$ $100 \mathrm{mg} \mathrm{L}^{-1}$ for 10 minutes.

The edible coatings were prepared at a concentration of $3 \%$ cassava starch by adding 30 grams of starch in 1 liter of distilled water (Henrique; Cereda, 1999). The solutions were heated in a water bath under constant stirring until reaching $70{ }^{\circ} \mathrm{C}$, which is the gelatinization temperature of cassava starch. The solutions were then naturally cooled until $25{ }^{\circ} \mathrm{C}$. The propolis incorporation in the coating soultions was carried out by adding commercial ethanolic extract of propolis at concentrations of $33 \%$ and $66 \%$, relative to the total starch, while stirring until total homogenization. This process was conducted after the solutions were cooled. The propolis extract used had 30\% total soluble solids and $11 \%$ minimum dry matter.

The fruits were randomly divided into four groups, one control (C) and three treatments: 3\% cassava starch (CS), 3\% cassava starch $+33 \%$ propolis $(\mathrm{CS}+\mathrm{P} 33 \%)$ and $3 \%$ cassava starch $+66 \%$ propolis (CS + P66\%). The fruits under investigation were dipped in the treatments for 30 seconds and the control fruits were immersed only in distilled water. All fruits were naturally dried at room temperature on a wire mesh with half-inch openings. After drying, they were then placed in polypropylene trays with perforated lids, each tray containing about 150 grams of fruit, representing a repetition. Each treatment consisted of three repetitions and from day 0 the fruits were analyzed every 4 days over a period of 16 days. The quantification of the vitamin $\mathrm{C}$ levels was performed 
by colorimetry, using 2,4-dinitrophenylhydrazine and results expressed in mg of ascorbic acid per $100 \mathrm{~g}$ of pulp according to Strohecker and Henning (1967). The total phenolic content was determined using the Folin-Ciocalteu reagent, wherein $0.5 \mathrm{~mL}$ of extract from each sample were added to tubes containing 2.5 $\mathrm{mL}$ of $10 \%$ Folin-Ciocalteu solution. The results were expressed in mg of gallic acid equivalents per 100 grams of the fruit (mg GAE. $100 \mathrm{~g}^{-1}$ ) (Waterhouse, 2002). The total anthocyanin contents were determined using the $\mathrm{pH}$ differential method proposed by Giusti and Wrolstad (2001). This method expresses the monomeric antchonyanin content, calculated as cianidin-3glucoside (Molecular Weight $=449.2$ ). The results were expressed as milligrams of cyanidin 3-glucoside equivalents per $100 \mathrm{~g}$ of fresh weight. The determination of the total antioxidant activity was carried out by the DPPH and $\mathrm{ABTS}^{+}$methods. For the DPPH assay the methodology adopted was based on the capture of the DPPH radical (2,2-diphenyl-1-picrylhydrazyl), which produces a decrease in absorbance at $515 \mathrm{~nm}$ (Rufino et al., 2007a). Based on this methodology, the $\mathrm{EC}_{50}$ parameter, which indicates the amount of antioxidant required to reduce $50 \%$ of the initial DPPH concentration, and the percent of free radical scavenging (\% FRS) where calculated. The two representations are useful when analyzed together, providing a broader view of the antioxidant capacity of fruits. The other method used to evaluate the antioxidant activity is based on the ability of antioxidants to capture the $\mathrm{ABTS}^{+{ }^{+}}$radical (2,2'-azino-bis(3-ethylbenzothiazoline-6-sulphonic acid), and the results expressed as $\mu \mathrm{M} \mathrm{TEAC/g}$ of fruit (Rufino et al., 2007b).

The Sisvar software (Ferreira, 2011) was used for statistical analysis of the variables. The variance analysis was conducted through the F test, to verify the difference among the treatments. The averages of the treatments, when significant, were compared, by the Scott-Knott test, to $5 \%$ of probability. When a significant difference in the interaction among the factors was found, regression analysis was carried out. The results were also submitted to principal component analysis (PCA) and were preprocessed by auto scaling before the analysis using the Chemoface software (1.4) (Nunes et al., 2012).

\section{RESULTS AND DISCUSSION}

Vitamin $\mathrm{C}$ is considered an important nutritional component in strawberries and may present variations in content among cultivars and as a function of environmental conditions (Pineli et al., 2011). The average vitamin $\mathrm{C}$ content found in 'Camino Real' strawberries in the present study $\left(71.95 \mathrm{mg} 100 \mathrm{~g}^{-1}\right)$ was higher than that reported by Pineli et al. (2011) (46.58mg $\left.100 \mathrm{~g}^{-1}\right)$. The same previously cited authors observed a vitamin $\mathrm{C}$ content of $31.45 \mathrm{mg} 100 \mathrm{~g}^{-1}$ fruit in the 'Osogrande' cultivar and Cordenunsi, Nascimento and Lajolo (2003) reported levels of 62 and $44 \mathrm{mg} 100 \mathrm{~g}^{-1}$ fruit of cultivars 'Campineiro' and 'Dover', respectively, demonstrating the high level of this nutrient in the 'Camino Real'cultivar.

The vitamin $\mathrm{C}$ content in the strawberries was affected by the interaction between storage time and the different coatings (Figure 1). There was a tendency towards an increase in the levels during storage for fruits of all treatments, those coated with CS + P66\% presenting a higher content than fruits submitted to the other treatments at 8 and 12 days, while at those same evaluation times, the non-coated fruits had the lowest levels. At the end of the storage time, however, there was no difference among treatments, indicating that the use of the coatings tested was not effective in the maintenance or increase of vitamin $\mathrm{C}$ levels in 'Camino Real' strawberries. The vitamin C content increase in the fruit can be associated with the water loss during storage, resulting in the concentration of the solids present therein. According to Chiumarelli and Hubinger (2012), cassava starch-based coatings can assist in reducing water loss, but when relating the increased vitamin $\mathrm{C}$ content during storage to the high water loss, it is found that the use of the coating was not effective for this purpose. Some studies report, unlike that observed in the present study, that there is ascorbic acid reduction in stored fruit (Bender et al., 2010; Calegaro; Pezzi; Bender, 2002; Cardoso et al., 2012; Cordenunsi; Nascimento; Lajolo, 2003) and other authors state that the use of different edible coatings can help reduce these losses (Atress et al., 2010; Gol; Patel; Rao, 2013; Wang; Gao, 2013), by promoting gas permeability reduction, thus reducing the respiration rate and consequently the oxidative reactions responsible for ascorbic acid degradation.

Phenolic compounds, together with compounds such as vitamin C, are responsible for the total antioxidant activity of food and act by preventing free radicals formation, which positively contributes to human health (Romero et al., 2009; Van De Velde et al., 2013). The total phenolic compounds were simultaneously affected by the treatments and the storage time, the three coated fruit groups showing very 
similar behavior, differing from the control at 4 and 12 days (Figure 2). At 8 days, the highest phenolic compound content was observed in the fruits coated with CS (332.72 $\mathrm{mg} \mathrm{EAG} \mathrm{g}^{-1}$ ), but at the end of the experimental period there was no difference among treatments in relation to this variable, indicating that after 16 days of cold storage the edible coatings tested herein were not effective to differentiate the coated fruits from those untreated, as to the phenolic compound content. A similar result was observed by Duan et al. (2011), when testing different coatings on fresh blueberries stored for 12 days. It was expected that edible coatings could act reducing the oxygen permeability (Chiumarelli; Hubinger, 2012) and thus prevent the oxidation of phenolics and that the added propolis could increase the content of total phenolic compounds.

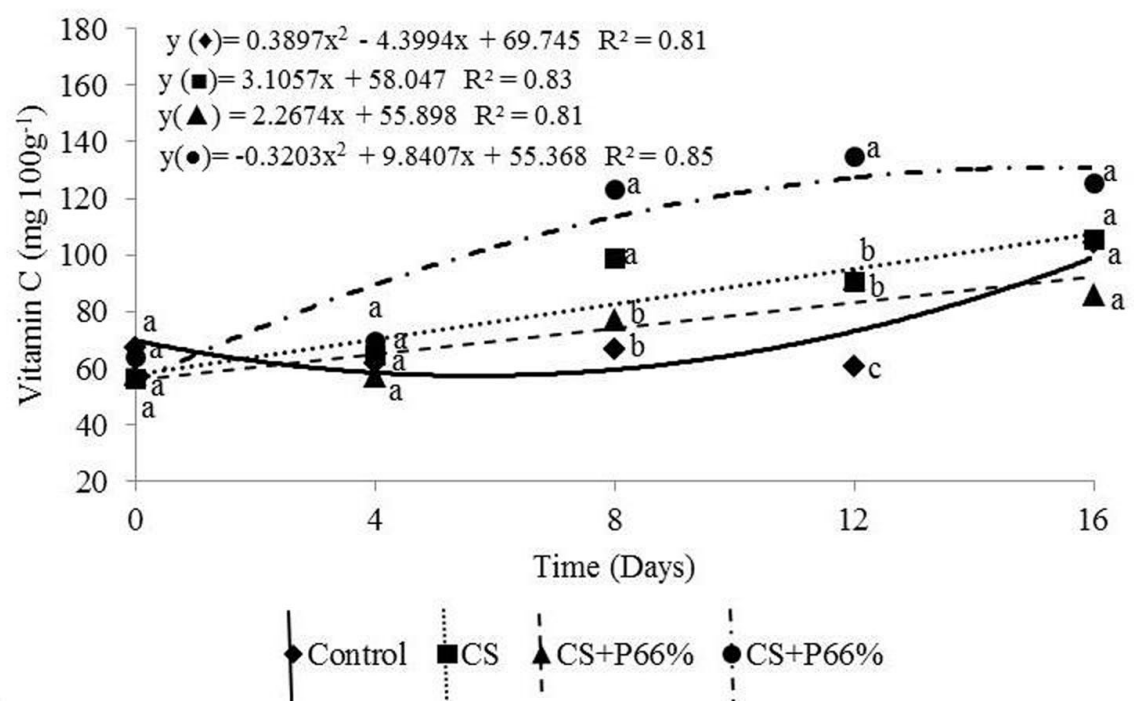

Figure 1: Effect of edible coatings on the vitamin C levels of 'Camino Real' strawberries stored for 16 days under refrigeration. Averages followed by the same letter within each time, do not differ among themselves by the Scott-Knott test at 5\%.

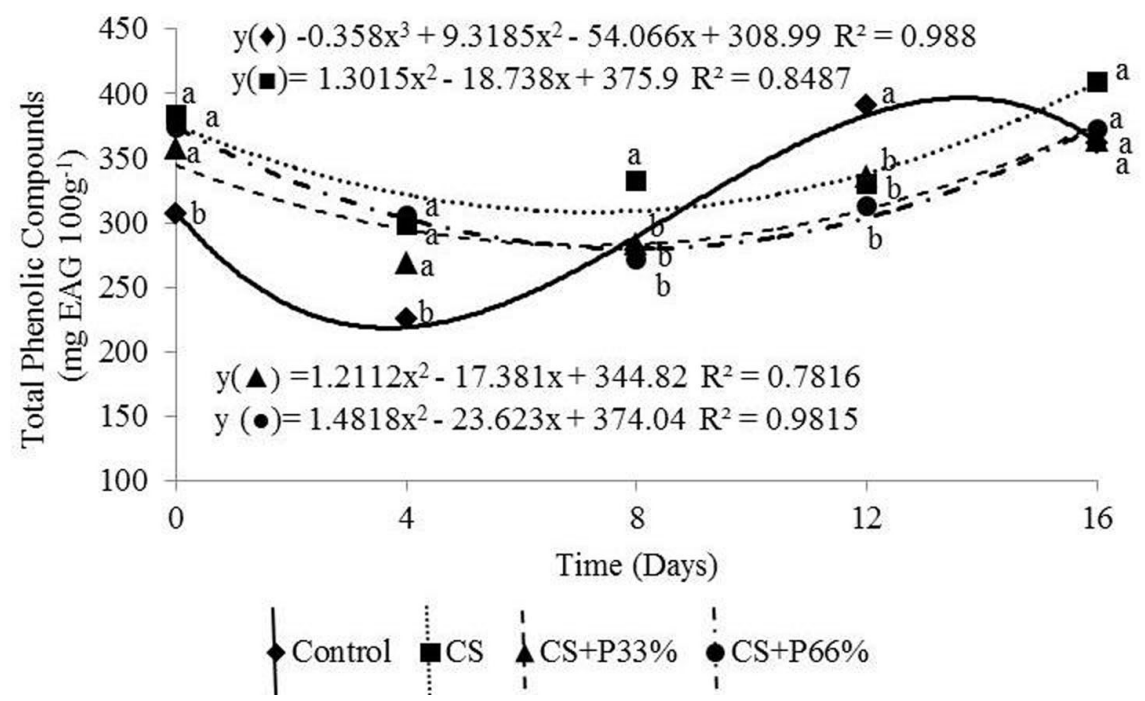

Figure 2: Effect of edible coatings on the total phenolic compounds levels of 'Camino Real' strawberries stored for 16 days under refrigeration. Averages followed by the same letter within each time, do not differ among themselves by the Scott-Knott test at $5 \%$. 
Overall, there was no great variation in phenolic content in the fruit during storage, and this is consistent with the study of Kevers, Falkowski and Tabart (2007), who found that in a wide variety of fruits, including strawberries, there was no reduction of these compounds during storage. Since at the end of the experimental time the treatments did not differ from the control in the present study, one can infer that the cassava starch based matrix used does not harm the maintenance of these compounds in the fruits, it being a good alternative if its benefit in maintaining other quality attributes is proven. We expected an increase in the phenolic content in the strawberries coated with cassava starch incorporated with propolis, since it is rich in these compounds (Teixeira et al., 2010). Possibly, the concentration of propolis used was not sufficient to significantly increase the phenolic content. Such a result makes it difficult to exploit the use of propolis for coatings, since at higher concentrations, its addition may significantly change the flavor of the fruit, causing consumer rejection.

As observed in Figure 3, there was variation in the anthocyanin content among the different treatments during storage. At time 0 the fruits treated with CS + P66\% showed the highest levels, but there was a decrease over time, and from the 8th day this treatment showed the lowest anthocyanin level by the end of storage, showing that CS + P66\% was ineffective in maintaining anthocyanin content in stored strawberry fruit. Despite the variation undergone during the storage, at the end of 16 days, the control fruit presented higher content compared to the coated fruit, a result similar to that reported by Garcia et al. (2012), who, when using a cassava starch based coating (3\%) on minimally processed strawberry, observed higher anthocyanin levels in uncoated fruits after 15 days. Similarly, Gol, Patel and Rao (2013) reported that strawberries coated with carboxymethyl cellulose and hydroxymethyl cellulose in combination with chitosan showed lower anthocyanin content than the uncoated fruit when stored for 12 days at $11{ }^{\circ} \mathrm{C}$. Since polysaccharide based coatings have low oxygen permeability, coated fruits typically exhibit a reduced respiratory rate (Chiumarelli et al., 2010), therefore, the high anthocyanin content in the uncoated fruit may be associated with increased pigment synthesis, resulting in a possible higher respiration rate. It is known that fruits rich in phenolic compounds, particularly anthocyanins, usually have the highest antioxidant capacity (Günduz; Ozdemir, 2014). The 'Camino Real' cultivar had an average of 54.66 mg 100 $\mathrm{g}^{-1}$ of anthocyanins, a quantity higher than that found by Pineli (2011) in fruits of the same cultivar (29.29 mg 100 $\left.\mathrm{g}^{-1}\right)$ and Jin et al (2011) in the cultivars 'Earliglow' (40 $\left.\mathrm{mg} 100 \mathrm{~g}^{-1}\right)$ and 'Allstar' $\left(20 \mathrm{mg} 100 \mathrm{~g}^{-1}\right)$ stored at $5^{\circ} \mathrm{C}$. The variation in the content found between the same cultivar as well as among other cultivars can be attributed to climatic and environmental differences of the locations where the fruits were produced, storage and the ripening stage at harvest (Crecente-Campo et al., 2012).

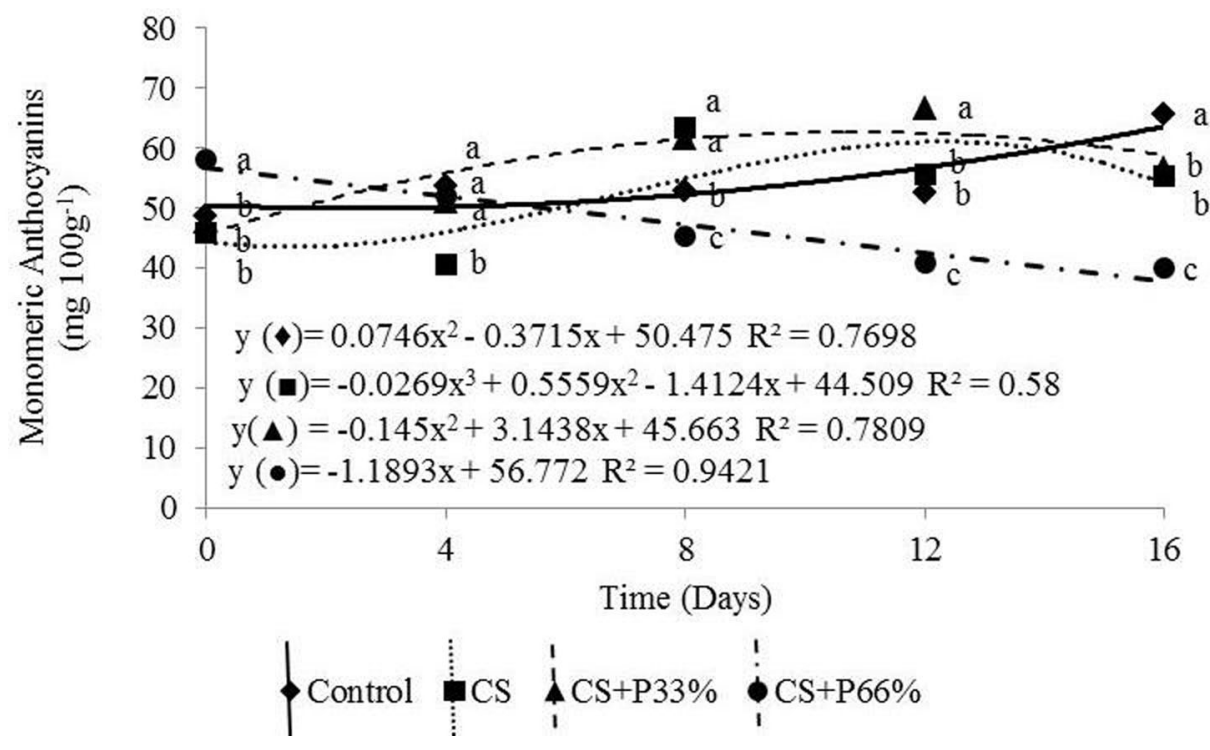

Figure 3: Monomeric anthocyanins of 'Camino Real' strawberries stored for 16 days under refrigeration. Averages followed by the same letter within each time do not differ among themselves by the Scott-Knott test at 5\%. 
The antioxidant capacity of strawberries determined by the DPPH and ABTS reduction methods was statistically affected by the interaction between the treatment and storage time. Comparing the $\% \mathrm{FRS}$ at the beginning and end of storage, there was no reduction of capacity, as can be seen in Figure 4A. At 4 and 8 days, the fruits coated with CS and those uncoated showed a higher percentage of free radical scavenging ( $\%$ FRS), while at these same evaluation times the treatments with propolis $(\mathrm{CS}+\mathrm{P} 33 \%$ and $\mathrm{CS}+\mathrm{P} 66 \%)$ had a reduction in the $\%$ FRS. At 8 days when the $\%$ FRS of fruit coated with CS appeared superior to the others, the phenolic content in fruits of this fruit group was also higher, showing a possible direct relationship between the variables at this evaluation time. Silva et al. (2006) reported that commercial propolis extracts have DPPH free radical sequestering ability and that this activity is correlated with the phenolics and flavonoid contents. At the end of the storage time there was no difference in antioxidant activity of fruits from the different treatments, however the CS-coated fruit maintained a higher \%FRS during storage. Wang and Gao (2013) report that the sequestering capacity of free radicals in strawberries coated with chitosan was superior to that of the uncoated fruit at the end of 9 days of storage at $5{ }^{\circ} \mathrm{C}$. It can be inferred that the incorporation of propolis, aiming to increase the antioxidant activity in strawberries, was not effective at the concentrations used.

We observed an $\mathrm{EC}_{50}$ reduction tendency in the treatments evaluated, which means the capacity to reduce free radicals had improved over the storage period (Figure 4B). Although at the end of 16 days all the contents of fruit from the evaluated treatments showed to be statistically similar, at 4 and 8 days of storage, the fruit treatment with $\mathrm{CS}+\mathrm{P} 33 \%$ presented higher $\mathrm{EC}_{50}$ index values, while fruits of the CS-only treatment, at eight days, showed better capacity to reduce the DPPH radical.

As the $\mathrm{EC}_{50}$ index reduced, there was a tendency towards an increase in the antioxidant activity detected by the ABTS method (Figure 4C). The opposite behavior of these variables is consistent, since the lower the $\mathrm{EC}_{50}$ index, the better the sample performance in sequestering the DPPH radical, i.e., higher sample antioxidant activity. Therefore, the combined analysis of antioxidant activity by two methods allows us to conclude that there was a slight increase in the antioxidant capacity of the fruit throughout the 16 days. Furthermore, when analyzing the phenolic compounds graph profile (Figure 2), there is an increase in the phenolics as well as the antioxidant activity with the ABTS method, consistent with the information reported by Gunduz et al. (2014), who claim that there is a strong relationship between total phenolics, anthocyanins and the antioxidant capacity of strawberries. From the 12th day until the last evaluation time, control samples and those coated with CS + P33\%, which had already displayed a lower antioxidant capacity throughout the experimental period, differed statistically from the others, presenting lower values and indicating that the addition of propolis was not a determining factor in the growth and maintenance of this variable in 'Camino Real' strawberries. According to work by RoblesSánchez et al. (2013), alginate-based coating with added ascorbic acid is effective in maintaining and increasing the antioxidant activity of mangos, evaluated by the ABTS and DPPH methods, suggesting the need for further studies on the use of propolis as an antioxidant agent, as well as tests to obtain the best doses for its application in strawberries.

The principal component analysis is shown in Figure 5, encompassing all variables evaluated herein, for fruits evaluated at five cold storage times. The figure contains the scores, which show that the first two principal components explain $66.08 \%$ of the total variability present in the data set, and the weights, that reveal the relationship among the samples based on the bioactive compounds quantified during storage of the coated strawberries.

Principal component analysis allowed to group the samples into three main groups demonstrating the similarities and differences, verifying a distinction among samples predominantly by storage time rather than the coatings used on the fruits. It can also be noted that samples at intermediate times differed from each other in a more pronounced way. Some samples did not fit into either group, presenting characteristics that stood out individually.

The vectors that represent the variables have practically the same distance in relation to Point 0 , indicating that the weights of these variables were not sufficiently different so that the samples could be located at different points in a quadrant. Furthermore, it is possible to observe that most of the compounds of interest are located on the positive X quadrant, the sample Group III being the most positively correlated with these compounds of interest. The DPPH variables $\left(\mathrm{EC}_{50}\right.$ and $\left.\mathrm{FRS} \%\right)$ were located at the ends of the $\mathrm{X}$ axis, which is consistent with the negative correlation that exists between what they represent. 

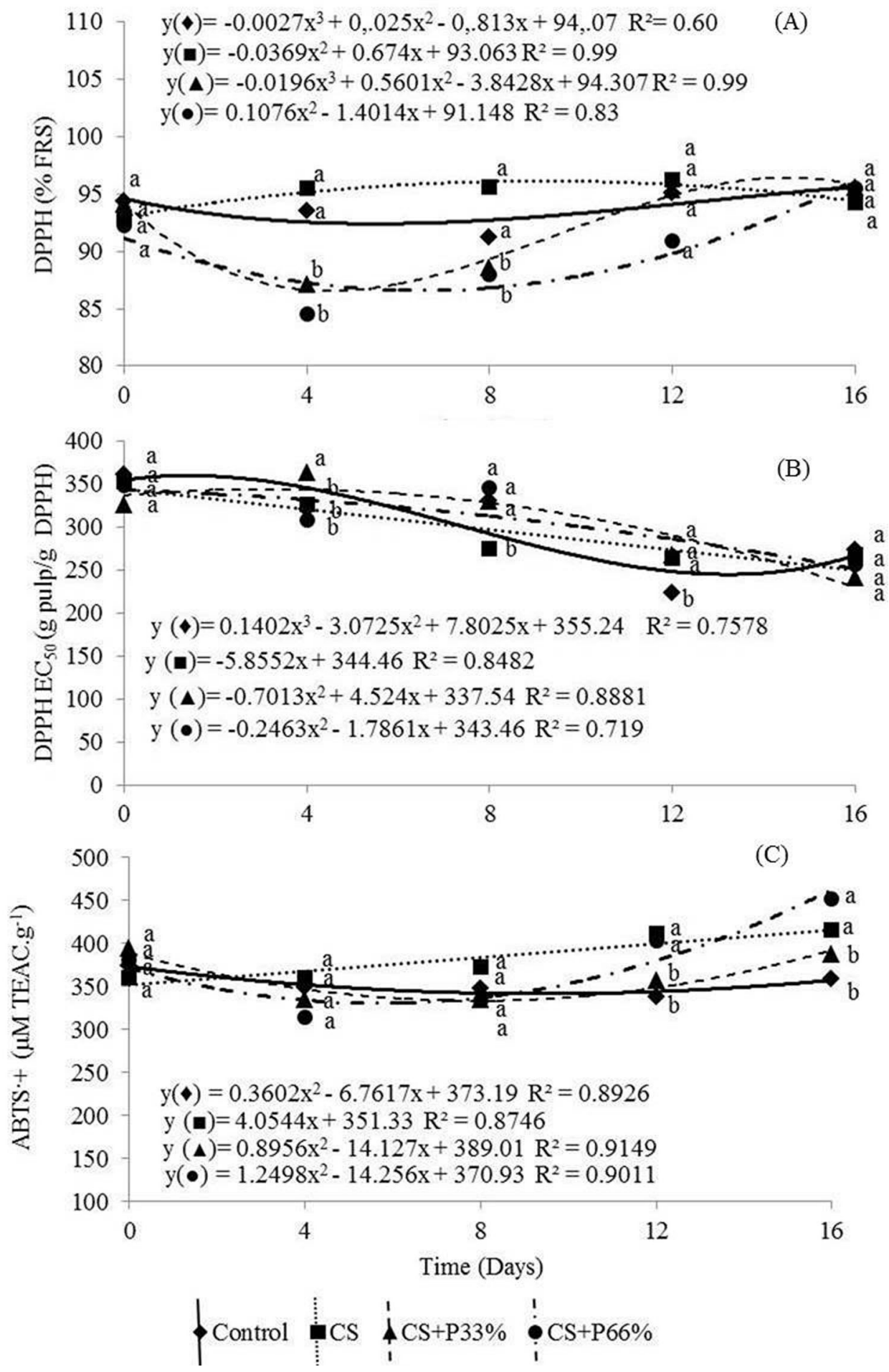

Figure 4: Effects of edible coatings on the antioxidant activity by the DPPH method - \%FRS (A) and EC50 index (B) - and by the ABTS method (C) of 'Camino Real' strawberries stored for 16 days under refrigeration. Averages followed by the same letter within each time, do not differ among themselves by the Scott-Knott test at 5\%. 


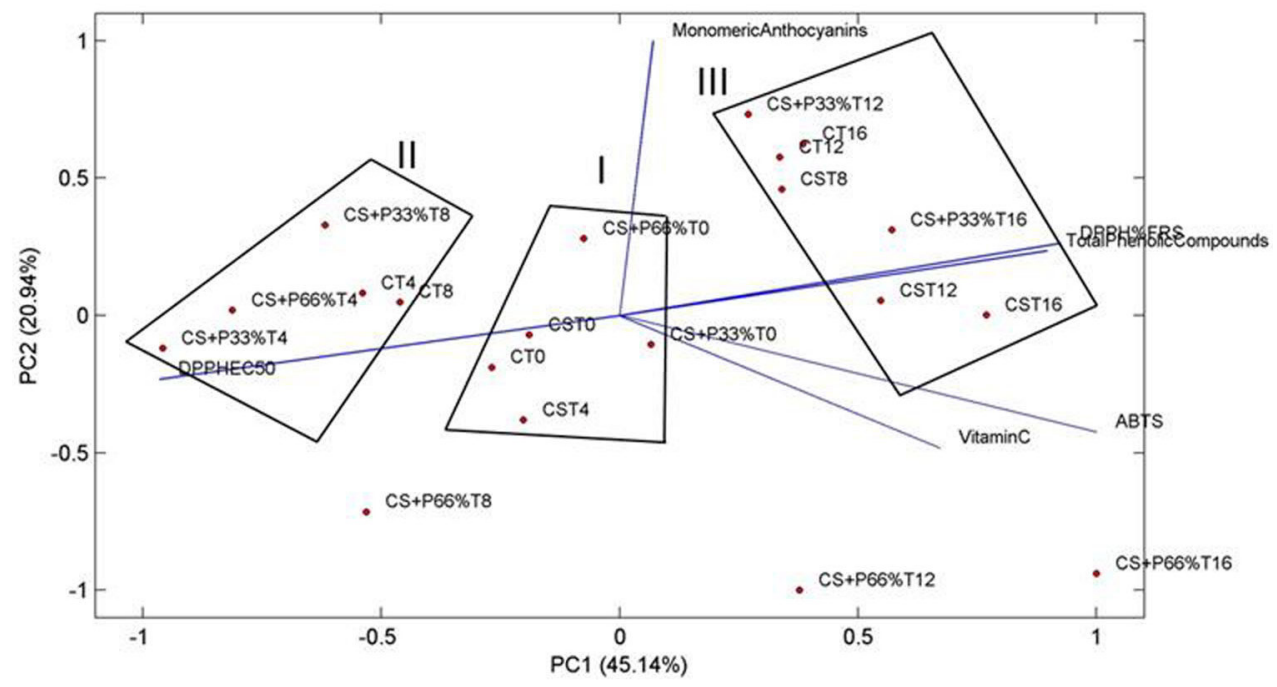

Figure 5: Principal component analysis (PCA). $C=$ control; $C S=$ cassava starch; $C S+P 33 \%=$ cassava starch $+33 \%$ propolis; $\mathrm{CS}+\mathrm{P} 66 \%=$ cassava starch $+66 \%$ propolis; $\mathrm{T} 0=0$ days; $\mathrm{T} 4=4$ days; $\mathrm{T} 8=8$ days; $\mathrm{T} 12=12$ days; $\mathrm{T} 16=16$ days.

It can be seen that the storage time was the determining factor in the characterization of the Group I samples. The sample of Time 4, which grouped with the Time 0 sample, was that coated with CS, which may indicate that these fruits are characterized by the same properties of fruits of the different treatments evaluated at Time 0 , showing the effectiveness of this treatment during the first days as to the levels of the compounds evaluated herein. The sample CS + P33T4 (Group II), which is close to the $\mathrm{EC}_{50}$ variable, was that which resulted in fruit with higher values for this variable. Other samples, such as fruits treated with CS + P33\%T8 and CST8, presented a higher anthocyanin content, positioning in the $\mathrm{Y}+$ quadrants.

Group III stood out compared to the others because of the total phenolic compound content and antioxidant activity by the DPPH method. These two variables are positively correlated and influenced samples equally.

The sample $\mathrm{CS}+\mathrm{P} 66 \%$, as well as CS, after 16 days of storage, approached the antioxidant variable by the ABTS method for presenting the highest activity at this time, as shown in Figure 4C.

\section{CONCLUSIONS}

The coating with $66 \%$ of propolis promoted higher Vitamin $\mathrm{C}$ content than fruits submitted to the other treatments at 8 and 12 days of storage. The coatings tested herein were not efficient to maintain the anthocyanin content in 'Camino Real' strawberries. Treatment with CS resulted in fruit with a higher and more constant capacity for free radical scavenging at the intermediate storage times. The addition of propolis, at the concentrations used, was not sufficient to maintain or increase the antioxidant capacity and phenolic content of strawberries during cold storage, showing the need to investigate other concentrations or products for which such addition is feasible and effective.

\section{REFERENCES}

ATRESS, A. S. H. et al. Improving strawberry fruit storability by edible coating as a carrier of thymol or calcium chloride. Journal of Horticultural Science \& Ornamental Plants, 2(3):88-97, 2010.

BANKOVA, V.; CASTRO, S. L.; MARCUCCI, M. Propolis: recent advances in chemistry and plant origin. Apidologie, 31(1):3-15, 2000.

BENDER, R. J. et al. Armazenagem de morangos cv. Camarosa e cv. Verão em atmosfera modificada. Acta Scientiarum.

Agronomy, 32(2):285-292, 2010.

BREWER, M. S. Natural antioxidants: Sources, compounds, mechanisms of action, and potential applications. Comprehensive Reviews in Foos Science and Food Safety, 10(4):221-247, 2011.

CALEGARO, J. M.; PEZZI, E.; BENDER, R. J. Utilização de atmosfera modificada na conservação de morangos em pós-colheita. Pesquisa Agropecuária Brasileira, 37(8):1-6, 2002. 
CARDOSO, L. M. et al. Qualidade pós-colheita de morangos cv. 'diamante' tratados com cloreto de cálcio associado a hipoclorito de sódio. Alimentos e Nutrição, 23(4):583588, 2012.

CHIUMARELLI, M. et al. Cassava starch coating and citric acid to preserve quality parameters of fresh-cut "Tommy Atkins" mango. Journal of Food Science, 75(5):E297-E304, 2010.

CHIUMARELLI, M.; HUBINGER, M. D. Stability, solubility, mechanical and barrier properties of cassava starch Carnauba wax edible coatings to preserve fresh-cut apples. Food Hydrocolloids, 28(1):59-67, 2012.

CORDENUNSI, B. R.; NASCIMENTO, J. R. O.; LAJOLO, F. M. Physico-chemical changes related to quality of five strawberry fruit cultivars during cool-storage. Food Chemistry, 83(2):167-173, 2003.

CRECENTE-CAMPO, J. et al. Color, anthocyanin pigment, ascorbic acid and total phenolic compound determination in organic versus conventional strawberries (Fragaria ananassa Duch, cv Selva). Journal of Food Composition and Analysis, 28(1):23-30, 2012.

DUAN, J. et al. Effect of edible coatings on the quality of fresh blueberries (Duke and Elliott) under commercial storage conditions. Postharvest Biology and Technology, 59(1):71-79, 2011.

FERREIRA, D. F. Sisvar: a computer statistical analysis system. Ciência e Agrotecnologia, 35(6):1039-1042, 2011.

GARCIA, L. C. et al. Effect of antimicrobial starch edible coating on shelf-life of fresh strawberries. Packaging Techology and Science, 25(7):413-425, 2012.

GIUSTI, M. M.; WROLSTAD, R. E. Anthocyanins: Characterization and measurement with UV-visible spectroscopy. In: WROLSTAD, R. E. Current protocols in food analytical chemistry. New York: J. Wiley, p. 1-13, 2001.

GOL, N. B.; PATEL, P. R.; RAO, T. V. R. Improvement of quality and shelf-life of strawberries with edible coatings enriched with chitosan. Postharvest Biology and Technology, 85(1):185-195, 2013.

GÜNDÜZ, K.; OZDEMIR, E. The effects of genotype and growing conditions on antioxidant capacity, phenolic compounds, organic acid and individual sugars of strawberry. Food Chemistry, 155(1):298-303, 2014.

HENRIQUE, C. M.; CEREDA, M. P. Utilização de biofilmes na conservação pós-colheita de morango (Fragaria ananassa Duch) CV IAC Campinas. Ciência e Tecnologia de Alimentos, 19(2):231-233, 1999.
JIN, P. et al. Effect of cultural system and storage temperature on antioxidant capacity and phenolic compounds in strawberries. Food Chemistry, 124(1):262-270, 2011.

KATIRCIOGLU, H.; MERCAN, M. Antimicrobial activity and chemical compositions of Turkishn propolis from different region. African Journal of Biotechnology, 5(11):11511153, 2006.

KEVERS, C.; FALKOWSKI, M.; TABART, J. et al. Evolution of antioxidant capacity during storage of selected fruits and vegetables. Journal of Agricultural and Food Chemistry, 55(21):8596-8603, 2007.

MCHUGH, T. H. Protein-lipid interactions in edible films and coatings. Food/Nahrung, 44(3):148-151, 2000.

MINAS GERAIS. Secretaria de Estado de Meio Ambiente e Desenvolvimento Sustentável. Zoneamento ecológicoeconômico do Estado de Minas Gerais - ZEE-MG. Belo Horizonte, 2008. Available in: <http://www.zee.mg.gov.br/ pdf/componentes_geofisico_biotico/4clima.pdf>. Acess in: June 09, 2015.

NUNES, C. A. et al. Chemoface: A novel free user-friendly interface for chemometrics. Journal of the Brazilian Chemical Society, 23(11):2003-2010, 2012.

OSZMIANSKI, J.; WOJDYLO, A. Comparative study of phenolic content and antioxidant activity of strawberry puree, clear, and cloudy juices. European Food Research, 228(4):623631, 2009.

PINELI, L. L. O. et al. Antioxidants and other chemical and physical characteristics of two strawberry cultivars at different ripeness stages. Journal of Food Composition and Analysis, 24(1):11-16, 2011.

PINTO, M. S. et al. Evaluation of antiproliferative, anti-type 2 diabetes, and antihypertension potentials of ellagitannins from strawberries (Fragaria ananassa Duch.) using in vitro models. Journal of Medicinal Food, 13(5):1027-1035, 2010.

PODSEDEK, A. Natural antioxidants and antioxidant capacity of Brassica vegetables: A review. LWT - Food Science and Technology, 40(1):1-11, 2007.

POKORNÝ, J. Antioxidants in Food Preservation. In: RAHMAN, M. S. Handbook of Food Preservation. New York: CRC Press, 2007. p.259-286.

ROBLES-SÁNCHEZ, R. M. et al. Influence of alginate-based edible coating as carrier of antibrowning agents on bioactive compounds and antioxidant activity in fresh-cut Kent mangoes. LWT - Food Science and Technology, 50(1):240-246, 2013. 
ROMERO, I. et al. Influence of the stage of ripeness on phenolic metabolism and antioxidant activity in table grapes exposed to different $\mathrm{CO}_{2}$ treatments. Postharvest Biology and Technology, 54(2):118-121, 2009.

RUFINO, M. S. M. et al. Metodologia científica: determinação da atividade antioxidante total em frutas pela captura do radical livre DPPH. Fortaleza: Embrapa, 4p. (Comunicado técnico, 127), 2007a.

RUFINO, M. S. M. et al. Metodologia científica: determinação da atividade antioxidante total em frutas pela captura do radical livre ABTS ${ }^{++}$. Fortaleza: Embrapa, 4p. (Comunicado técnico, 128), 2007b.

SÁNCHEZ-GONZÁLEZ, L. et al. Effect of hydroxypropylmethyl cellulose and chitosan coatings with and without bergamot essential oil on quality and safety of coldstored grapes. Postharvest Biology and Technology, 60(1):57-63, 2011.

SCAZZOCCHIO, F. et al. Multifactorial aspects of antimicrobial activity of propolis. Microbiology Research, 161(4):327333, 2006.

SILVA F. L. et al. Anthocyanin pigments in strawberry. LWT Food Science and Technology, 40(2):374-382, 2007.

SILVA, J. F. M. et al. Correlation analysis between phenolic levels of Brazilian propolis extracts and their antimicrobial and antioxidant activities. Food Chemistry, 99(3):431-435, 2006.

STROHECKER, R.; HENNING, H. M. Analisis de vitaminas: métodos comprobados. Madrid: Paz Montalvo, 1967. $428 p$.
SZAJDEK, A.; BOROWSKA, E. J. Bioactive compounds and healthpromoting properties of berry fruits: a review. Plant Foods for Human Nutrition, 63(4):147-56, 2008.

TEIXEIRA, W. et al. Seasonal variation, chemical composition and antioxidant activity of Brazilian propolis samples. Evidence-Based Complementary and Alternative Medicine, 7(3):307-315, 2010.

VAN DE VELDE, F. et al. Bioactive compounds and antioxidant capacity of Camarosa and Selva strawberries (Fragaria ananassa Duch.). Foods, 2(2):120-131, 2013.

VANDENDRIESSCHE, T. et al. Effect of ripening andinter: cultivar differences on strawberry quality. LWT - Food Science and Technology, 52(1):52-70, 2012.

WANG, S. Y.; GAO, H. Effect of chitosan-based edible coating on antioxidants, antioxidant enzyme system, and postharvest fruit quality of strawberries (Fragaria aranassa Duch.). LWT - Food Science and Technology, 52(2):71-79, 2013.

WATERHOUSE, A. L. Polyphenolics: Determination of total phenolics. In: WROLSTAD, R. E. et al. Current Protocols in Food Analytical Chemistry. New York: John Wiley \& Sons, 2002. p. 1111-1118.

ZAHID, N. et al. Efficacy of ethanolic extract of propolis in maintaining postharvest quality of dragon fruit during storage. Postharvest Biology and Technology, 79(1):6972, 2013.

ZAHID, N. et al. Potential of chitosan-loaded nanoemulsions to control diferente Colletotrichum spp. and maintain quality of tropical fruit during cold storage. Journal of Applied Microbiology, 113(4):925-939, 2012. 